\title{
In Situ Analysis of DNA-Protein Complex Formation upon Radiation-Induced DNA Damage
}

\author{
Giulio Ticli ${ }^{1,2}$ and Ennio Prosperi ${ }^{1, *}$ \\ 1 Istituto di Genetica Molecolare “Luca Cavalli Sforza”, Consiglio Nazionale delle Ricerche (CNR), \\ 27100 Pavia, Italy; giulio.ticli@igm.cnr.it \\ 2 Dipartimento di Biologia e Biotecnologie, Università di Pavia, 27100 Pavia, Italy \\ * Correspondence: prosperi@igm.cnr.it
}

Received: 10 October 2019; Accepted: 14 November 2019; Published: 15 November 2019

\begin{abstract}
The importance of determining at the cellular level the formation of DNA-protein complexes after radiation-induced lesions to DNA is outlined by the evidence that such interactions represent one of the first steps of the cellular response to DNA damage. These complexes are formed through recruitment at the sites of the lesion, of proteins deputed to signal the presence of DNA damage, and of DNA repair factors necessary to remove it. Investigating the formation of such complexes has provided, and will probably continue to, relevant information about molecular mechanisms and spatiotemporal dynamics of the processes that constitute the first barrier of cell defense against genome instability and related diseases. In this review, we will summarize and discuss the use of in situ procedures to detect the formation of DNA-protein complexes after radiation-induced DNA damage. This type of analysis provides important information on the spatial localization and temporal resolution of the formation of such complexes, at the single-cell level, allowing the study of heterogeneous cell populations.
\end{abstract}

Keywords: DNA damage; DNA repair; DNA-interacting proteins; in situ analysis; immunofluorescence detection; live-cell imaging

\section{Introduction}

Cells in the human body are continuously exposed to a multitude of endogenous and exogenous agents, which can produce a broad range of DNA lesions, compromising the cell functionality. As a consequence of inefficient or absent DNA repair, DNA damage can lead to genome instability and mutation in DNA [1]. These defects may result in developmental abnormalities and/or in the cell transformation towards a malignant phenotype [2,3].

Radiations (e.g., UV light, X-rays, $\gamma$-rays) are one of the major exogenous sources of DNA damage producing different types of lesions, according to the wavelength and the physical nature (electromagnetic or particle) of the radiation. UV radiation is divided into three spectral regions (UV-A: 320-400 nm; UV-B: 290-320 nm; UV-C: 100-290 nm), with UV-B and UV-C being the most dangerous because they are able to induce nucleotide structural alterations, such as the dimerization of pyrimidine bases to form cyclobutane pyrimidine dimers (CPDs) or pyrimidine (6-4) pyrimidone photoproducts (6-4PPs) [4]. UV-A radiation may induce oxidatively generated DNA damage through photosensitization [4]. The more energetic ionizing radiation (IR) induces DNA damage through ionization and hydroxyl radical production, leading to the formation of DNA breaks, either at the single-strand (SSBs) or at the double-strand (DSBs) level, in addition to base oxidation and DNA-protein crosslinks $[5,6]$. In fact, exposure to IR is commonly used for the therapy of many types of tumor. Given that, the biological effects of radiation have been extensively studied to understand how the cell response to DNA damage may influence the efficacy of radiation therapy [7]. 
The mechanism by which cells cope with DNA damage has been, and still is, intensively investigated, for the reasons stated above. In the last decades, it has been shown that cells rely on several processes to deal with DNA damage, which now collectively constitute the DNA damage response (DDR) [8]. This term refers to pathways allowing cells to detect the occurrence of DNA lesions, signal their presence to arrest the cell cycle and promote the activation of specific DNA repair systems able to remove such lesions [9]. Preferential activation of DNA damage signaling and repair systems has been shown to directly depend on the type of lesion and the physiological status of the cell [10].

Independently from the DNA damage signaling and repair system considered, the DNA-protein complex formation represents a fundamental step of this intracellular cascade of events because it is required for the DNA lesion recognition and to trigger the recruitment of specific DNA repair factors, which take turns with a defined spatiotemporal sequence during the DNA repair event. Thus, the multiple proteins required for DNA damage signaling and repair need to bind to the DNA for carrying out their activity [11,12]. From early studies using in vitro approaches based on purified proteins in reconstituted systems, components of DDR pathways were identified. However, these methodologies were later considered incomplete and insufficient to address specific questions regarding the spatiotemporal characterization of these processes, taking into account the physiology and ultrastructure complexity of the cell [13]. For this reason, it has been necessary to develop new strategies to probe the formation of DNA-protein complexes in situ, to investigate the recruitment kinetics of DDR proteins at DNA damage sites, and to evaluate where they interact with DNA. These parameters may provide relevant information about the dynamics of these important cellular reactions.

The goal of this review is to cover and discuss the use of the most recent and sensitive methods and techniques to determine the formation of radiation-induced DNA-protein complexes at the cellular level. In fact, the in situ analysis is intended to detect these interactions and related biological processes in a cellular environment that is retained, as much as possible, close to the in vivo condition. A comparison of these techniques in terms of the advantages and limitations of each approach will be discussed.

\section{In Situ Detection of DNA-Protein Complex Formation}

The analysis of DDR factors binding to DNA, and in particular to DNA lesions, may be performed in situ, i.e., in intact cells, either: (i) after appropriate cell/tissue fixation that is necessary to retain these proteins at their activity site, or (ii) directly on living cells, providing that DNA and proteins of interest may be visualized under the microscope (e.g., through protein expression with a fluorescent tag). These methods have been often applied in combination with procedures enabling the induction of localized DNA damage.

The first approach requires an immunolabeling reaction (usually with fluorescently conjugated antibodies) directed to the protein of interest, when it may be identified as bound to DNA. Different procedures are available to perform such analysis, which in general consists of an in situ extraction of the unbound fraction so that only the DNA-bound molecules are subsequently fixed at the sites where DNA lesions are present [14-16].

The second approach is based on the more sophisticated technology of live-cell imaging through which the behavior of a DNA-binding protein, e.g., its relocation to DNA damage sites, may be monitored in living cells thanks to its expression in a form fused to a fluorescent tag, such as the green fluorescent protein (GFP) [17]. This technique enables the visualization of the protein of interest at on-going DNA repair sites, thus allowing direct spatiotemporal evaluation of its binding to DNA [18-22].

A schematic overview of both approaches is shown in Figure 1. 


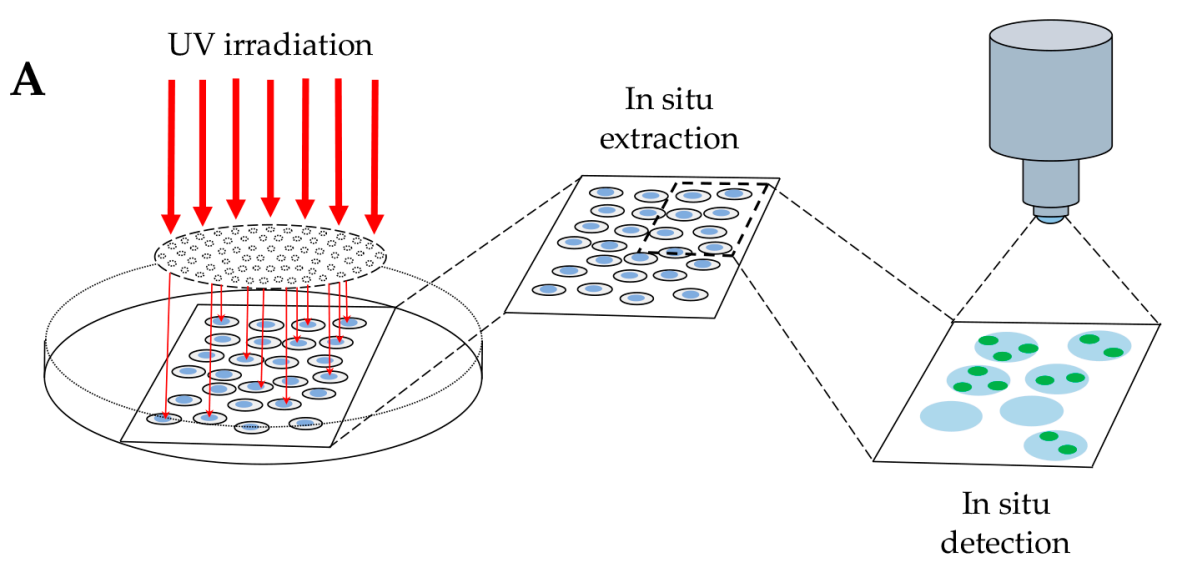

B

Localized laser irradiation

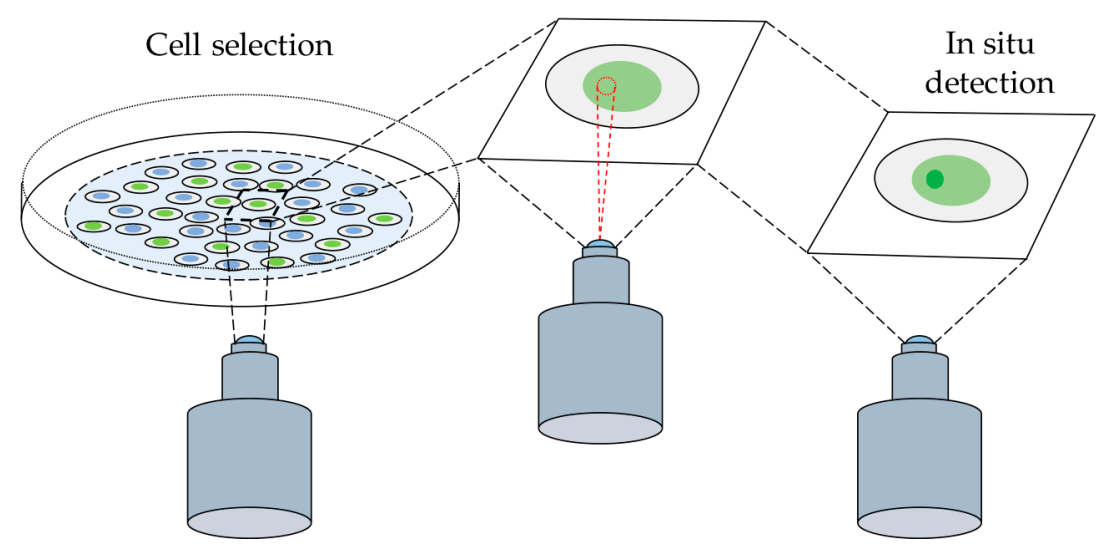

Figure 1. Detection of protein binding to DNA after radiation-induced DNA damage. (A) Schematic representation of cell exposure to UV radiation through a micropore polycarbonate filter to produce local DNA damage (see Section 2.1.1). The next step of in situ extraction allows the release of unbound molecules, enabling the final detection of protein bound to DNA, by immunofluorescence technique. (B) Cell exposure to local laser irradiation to detect protein binding to DNA by indirect immunofluorescence method, as above, or by direct visualization of the accumulation of a fluorescently-tagged protein at the site of DNA damage in living cells (see Section 2.2).

\subsection{Detection of DNA-Protein Complexes in Fixed Cells}

\subsubsection{Immunofluorescence-Based Techniques}

As stated above, a major caveat for this type of analysis is that immunofluorescence reaction must detect the protein of interest when it is bound to DNA (many authors referred to this association as "chromatin-bound fraction"). A practical approach introduced for different proteins known to bind DNA has been to rely on a fixation procedure that may distinguish the DNA-bound form. This has been the case for the "proliferating cell nuclear antigen" (PCNA), an important protein functioning as a platform for many DNA-binding factors participating in several DNA metabolic processes, including DNA replication and repair $[23,24]$. PCNA encircles the double helix when loaded onto DNA, and it is thus resistant to extraction [14,15]. However, for other proteins, and often for PCNA too, this procedure could not provide reliable information, given that simple fixation may retain part of unbound protein $[15,25]$. Thus, in situ detection has been most often performed after a detergent-based lysis step enabling the extraction of the unbound fraction while retaining proteins associated with DNA [26].

A significant improvement in the in situ detection of proteins bound to DNA has been obtained by limiting DNA damage to a small area of the nucleus, thereby ensuring that protein binding is detected only at this site. This condition was attained by coupling the immunofluorescence assay 
to an irradiation procedure that produces localized DNA damage in the nucleus of irradiated cells. In particular, cells were masked with a polycarbonate isopore membrane filter (pore size may be chosen from 3 to $8 \mu \mathrm{m}$ ), allowing the irradiation of defined areas in correspondence of its pores [27,28]. These filters have been extensively used in UV-induced DNA damage studies taking advantage of the physical properties of polycarbonate, which can efficiently absorb the entire spectrum of UV radiation. This technique, named micropore irradiation, has been employed to detect the recruitment of several proteins at local DNA damage sites. Typically, DNA binding factors, such as DDB2 and XPC, that recognize lesions on DNA during nucleotide excision repair (NER), PCNA (Figure 2), as well as repair enzymes, e.g., DNA nucleases, helicases, polymerases, ligases, and chromatin assembly factors, have been detected with this method [29-36].

A

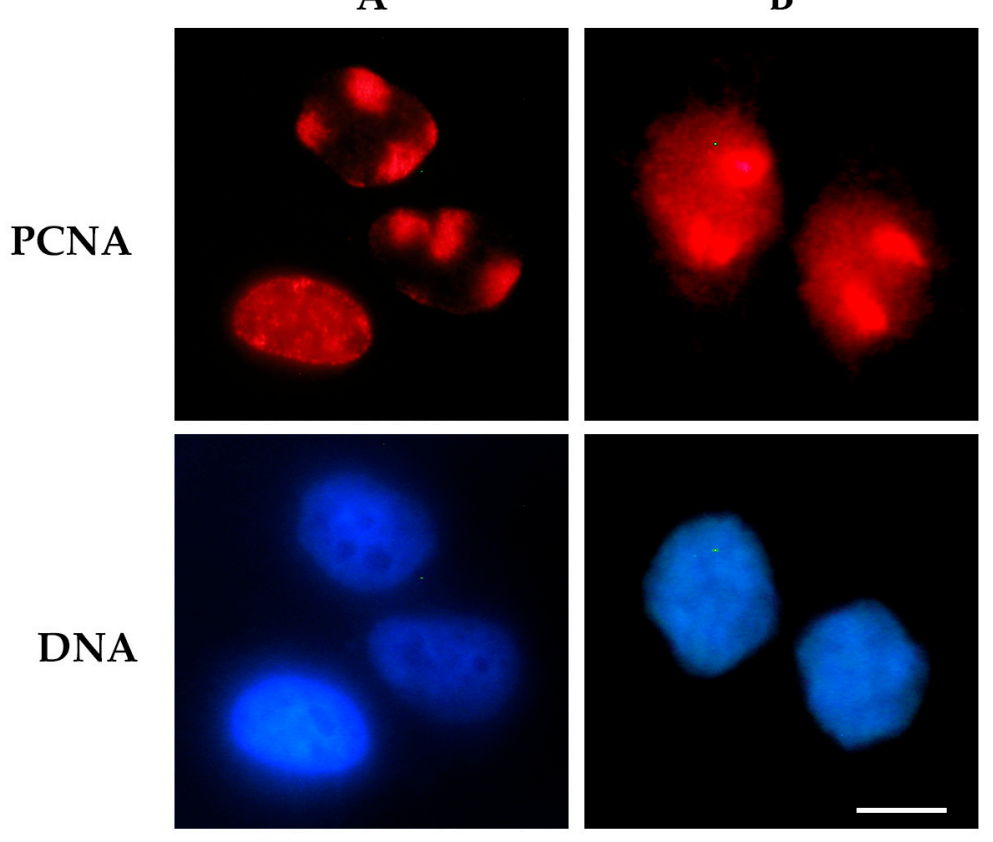

Figure 2. Detection of proliferating cell nuclear antigen (PCNA) protein bound to DNA after UV radiation-induced DNA damage. Cells were exposed to UV radiation $\left(30 \mathrm{~J} / \mathrm{m}^{2}\right)$ through a $3 \mu \mathrm{m}$ micropore polycarbonate filter to produce local DNA damage. In (A), the cells were processed for an in situ extraction to visualize only PCNA bound to DNA at local damage sites (red spots), or at sites of DNA replication (diffuse pattern) [24]. In (B), cells were directly fixed after UV irradiation to detect the total nuclear PCNA. In both panels, PCNA protein (red fluorescence) was detected by immunofluorescence staining with PC10 monoclonal antibody and an Alexa 594-conjugated secondary antibody. DNA was stained with Hoechst 33258 dye. Scale bar $=10 \mu \mathrm{m}$.

This protocol of irradiation has allowed the in situ detection of DNA binding of DDR factors, such as p53, at sites of IR-induced DNA damage [37]. The same procedure was used to rule out the presence of this protein at DNA damage sites after UV radiation [38]. In fact, in another study, p53 appeared to localize at sites of UV-induced DNA damage [39]; however, this result was obtained without the extraction of the unbound protein. It must be noted that an important control to safely establish the association of a given protein to DNA in situ, is based on a DNase I digestion step before fixation, which will remove the DNA-protein complex [37].

Other important applications of this technique include the detection of structural components of chromatin that interact with DNA, and how they are involved in the DDR. For instance, the study of histone deposition and chromatin reassembly after DNA damage has taken advantage of the micropore filter irradiation to demonstrate that after UV irradiation, new histone incorporation occurs at damaged sites [40]. In this study, a control DNase treatment was performed to verify that new histone H3 
deposition corresponded to the chromatin-bound fraction [40]. Another aspect investigated at local sites of DNA damage is the maintenance of epigenetic information after DNA damage. Acetylation of histone $\mathrm{H} 3$ at $\mathrm{K} 56$ (H3K56ac) has been recently detected in situ after UV-induced DNA damage [41], thus showing the possibility to study post-repair events at local sites in chromatin.

A possible critical aspect of this technique concerns the optimal localization of DNA repair proteins by immunofluorescence staining, since their visualization may be challenging according to the cell line and the protein itself. Given that, protein-specific extraction protocols were developed to improve the fluorescence signal. In particular, they were based on the combination of different detergent extraction procedures (e.g., Triton X-100 and Igepal) with diverse fixative solutions (e.g., ethanol, methanol-acetone, and formaldehyde), to stain only the chromatin-bound fraction of the protein of interest [25-27,32]. For instance, for proteins, such as DDB2 and XPG, a protocol performing detergent lysis simultaneously with fixation, was introduced to enable detection of these factors that were otherwise lost, or their amount reduced [32,42]. More recently, visualization at local DNA damage sites of the above factors, including XPC protein, has been improved by using a mild DNase I digestion before the immunoreaction. This procedure probably acts by making the epitope more accessible to the antibodies and has proved to work with different fixatives [43].

The use of polycarbonate filters is, however, limited to UV radiation because of its insufficient shielding properties (e.g., to X-rays and near-infrared light) [44]. Another issue of the technique is that the position of irradiated areas in the nucleus is randomly distributed, and hence specific nuclear regions (e.g., heterochromatin) cannot be selected before irradiation. Since the timing of DNA repair also depends on local chromatin compaction, the information obtained with this approach is, therefore, limited to the detection of a given protein at the irradiated area (a single frame of the overall process). In later studies, the micropore filter has been coupled with confocal microscopy imaging to irradiate living cells and track in real-time fluorescence-tagged proteins recruited at the DNA damage sites [28].

\subsubsection{Probe-Based Techniques}

Investigating the interaction among proteins and DNA in situ with conventional immunofluorescence techniques has the typical limitation imposed by the optical resolution of the microscope system. To cope with this problem, the proximity ligation assay (PLA) was developed as a sensitive and reliable method for the in situ detection of two molecules in close proximity to each other $(<40 \mathrm{~nm})[45]$.

This approach is based on a pair of oligonucleotide-conjugated probes that can, directly or indirectly, bind two molecules that are supposed to interact. The two oligonucleotides are designed to hybridize to two connector oligonucleotides, which are then ligated to form a circular DNA molecule only when the two probes are spatially close. The circular DNA is successively used as a template for the rolling circle amplification (RCA) reaction, together with fluorescently labeled nucleotides as substrate. Therefore, this system detects as a fluorescent spot, two molecules that are spatially close enough to allow the reaction to occur, thereby leading to the assumption that they are interacting [45]. The sensitivity and reliability of PLA are linked to the nature of the probes: The applications in situ are generally based on the use of two primary antibodies, characterized by binding to the target molecules with high specificity, and two species-specific, oligonucleotide-conjugated secondary antibodies (as probes). This two-step procedure guarantees the reduction in potential PLA binders cross-reactivity, which might be a serious concern especially when the target molecule is not abundant or when the antibody dissociation constant $(\mathrm{Kd})$ for the intended molecule is slightly different from the one for the cross-reactive molecule at similar concentrations [46].

In the last decade, PLA has been improved thanks to the development of new variants of the method that has been optimized according to the experimental needs, for instance, by enhancing probe specificity [47]. PLA has also been coupled with other techniques, such as flow cytometry, to provide subcellular localization assay (SLA), both enabling high-throughput data on spatial information and fluorescence quantitation [48]. A multi-well based platform has also been developed, under the name 
of "high-throughput imaging PLA (HiPLA), using a library of antibodies to probe nuclear proteins, and their associated post-translational modifications, with the nuclear lamina [49].

In principle, the amplification system of PLA is suitable for any study aiming to investigate protein-protein or DNA-protein complex formation, taking advantage of the large variety of available antibodies raised against specific target molecules and their post-translationally modified forms (e.g., acetylation, ubiquitination, phosphorylation). Recently, this technique was adapted for the use of non-adherent cells [50,51], further increasing the range of possible applications. In fact, PLA has been employed to investigate the binding of known DDR factors, such as MDC1, 53BP1, as well as histone $\gamma-\mathrm{H} 2 \mathrm{AX}$ to DSB [52], as well as new proteins, such as EXOSC10 [53], the androgen receptor variants [54], and karyopherin- $\alpha 2$ [55], providing important insight into their activity during DNA repair. In this regard, new PLA-based techniques have been developed, such as DI-PLA (DNA damage in situ ligation followed by proximity ligation assay) [56] and SIRF (in situ protein interactions at nascent and stalled replication forks) [57]. With DI-PLA, it is possible to localize with high accuracy DSBs at the single-cell level. In the original paper, DNA breaks were induced by exogenous expression of a restriction enzyme; however, the procedure may be easily used in cells exposed to radiation. After DNA damage, T4 DNA polymerase and T4 ligase enzyme are used, respectively, to blunt DSB ends and to ligate with high specificity a biotinylated oligonucleotide. PLA is then carried out using an antibody against biotin and a partner antibody against a DDR marker (e.g., $\gamma$-H2AX or 53BP1). In this way, DI-PLA allows the amplification of the fluorescence signal and, therefore, the detection in situ of a single DSB in proximity to a DDR protein, overcoming the necessity to use high levels of DNA damage [58].

A particular use of PLA for DNA-protein interaction has been proposed for the detection of protein binding to specific DNA sequences, by using DNA-binding probes for in situ hybridization, in combination with an antibody to a target protein. Circularization oligonucleotides are then hybridized to both PLA probes, ligated, and RCA reaction performed as in normal PLA [59]. This technique may thus be employed for studying protein binding to specific nuclear sequences after DNA damage.

The variation of the PLA method, named SIRF, was developed to study the protein and DNA-protein complexes at active and stalled replication forks at a single-cell level [57]. This method draws its inspiration from another important technique, the iPOND assay (isolation of proteins on nascent DNA) [60]. In particular, SIRF starts with the incorporation of the nucleoside analog 5'-ethylene-2'-deoxyuridine (EdU), which, once incorporated into DNA, may be biotinylated using click chemistry. After that, PLA is carried out using specific antibodies to biotin and a protein target of interest (e.g., 53BP1) [57], as described above. This technique is unique in that it detects the association of proteins with nascent DNA in situ, providing high temporal resolution, in addition to spatial information. In fact, the EdU labeling time is short enough $(8 \mathrm{~min})$ to infer that the protein binding to DNA occurs at the DNA synthesis site. Therefore, in this context, both DI-PLA and SIRF are efficient molecular tools for qualitative and quantitative studies on DNA repair systems providing in situ analysis with high resolution.

\subsection{Detection of DNA-Protein Complexes in Living Cells}

The techniques above described are characterized by limited spatial resolution, or do not allow the kinetic analysis of the protein binding to DNA, because they provide a freeze-frame; therefore, they are unsuitable for studying the dynamic binding of repair factors to DNA in living cells. These limitations were overcome by the advent of fluorescent proteins (e.g., GFP), and their derivatives, that may be expressed in living cells, thus making possible real-time studies [18-20]. This methodology was further used in combination with the use of a laser beam to produce DNA lesions in a sub-nuclear area. In fact, a focused laser beam allows micro-irradiation with high spatial resolution, in the range of a few microns $(\approx 2 \mu \mathrm{m})$, a nuclear region of interest (ROI), thus producing local DNA damage (Figure 1$)$. This approach was initially developed to study UV-induced DNA damage [61], but it was then adapted to induce SSBs and DSBs by cell pre-treatment with sensitizers, such as DNA dyes (Hoechst 33342) and 
halogenated thymidine analogs (BrdU, IdU) [19,62]. These compounds are less frequently used for this purpose because of their toxic effect on cells due to the oxidatively generated DNA damage induced during photosensitization, and because they may trigger multiple DNA repair processes [63].

One of the most relevant advantages of this approach is that visualization of DNA-protein complexes is easily accomplished with the use of plasmid vectors driving the transient or constitutive expression of a protein of interest, fused to a fluorescent tag. Therefore, the fluorescence live-cell imaging conditions combined with the laser micro-irradiation systems, represent a powerful tool for the in situ studies. This system allows monitoring in real-time the recruitment and subsequent release of DNA binding protein upon the DNA lesion formation. Crucial insights are obtained into the dynamics of protein-DNA interaction turnover, as well as the simultaneous analysis of multiple factors at DNA damage sites when they are available and expressed as fluorescent proteins with different color emission. Along with this, other methods, such as fluorescence recovery after photobleaching (FRAP) and fluorescence loss in photobleaching (FLIP), have been employed after laser micro-irradiation to further analyze and refine kinetic models of DNA-protein interaction, as for DNA damage signaling and repair factors $[64,65]$.

Live-cell imaging has been extensively used to investigate DNA damage signaling pathways and DNA repair processes, and many examples are reported in relevant and recent reviews $[12,19,65,66]$. Of particular interest are those studies in which quantitative determination of the recruitment and release kinetics at the DNA damage sites was performed for direct players and regulators of the various DNA repair processes. Specific parameters were estimated during NER, (i.e., XPA, XPC, PCNA, p21) [67-70], in the base excision repair (BER) process (i.e., XRCC1, OGG1, PARP-1) [71-77], as well as in the non-homologous end joining (NHEJ) process (i.e., Ku70/80 complex, DNA-PK, DNA Ligase III) [78-80]. Furthermore, calculation of several kinetic parameters, such as the ratio between protein-bound state and diffusive state over time, allowed the further deepening of theoretical models regarding DNA-protein, or protein-protein complex formation upon DNA damage, and the evaluation quantitatively of the spatiotemporal activity of DNA repair factors $[67,69,71,75]$.

A particular approach in detecting DNA-protein complexes consists of the expression of a fluorescent reporter (i.e., a GFP-labeled peptide or protein) that can bind DNA specifically to a given lesion (e.g., DSB), so that fluorescent localization of DNA damage is obtained in living cells [81]. Expression of the fluorescent GAM protein, or a peptide from 53BP1 protein, have provided localization of DSBs $[82,83]$. Very recently, UV-induced DNA damage recognition by fluorescently-tagged enzymes (photolyases), specifically binding to CPDs and 6-4PPs, has been proposed [84]. This technique provides a useful tool to detect these lesions in situ and to quantify their repair kinetics in real-time.

To study DNA-protein interactions in the other way round, the expression of a fluorescently-labeled plasmid containing a single lesion (e.g., an abasic site) has been recently proposed for monitoring the recruitment of endogenous proteins to specific lesions over time [85]. However, while the plasmid localization may be performed in vivo, detection of the protein is obtained after fixation and immunostaining to determine the co-localization of the fluorescent plasmid and the protein of interest.

Another interesting method allows the targeted disruption of protein interactions in living cells [86]. The procedure consists in anchoring to a defined cellular structure (e.g., a specific DNA sequence or regions) a GFP-fusion protein that interacts with a partner labeled with a different fluorescent protein (e.g., RFP), and monitoring the recruitment of the red protein to the site of the GFP-tagged one. This method may be applied under different conditions, including treatment with agents able to disrupt the interaction between the two proteins, thus providing important information on their association and the possibility to test the effect of small molecules, drugs, and even peptides [86].

A peculiarity of live-cell imaging techniques is that DNA lesions may be produced in specific nuclear regions. For instance, they have been used to discriminate the recruitment of DNA repair proteins at damaged sites in heterochromatin vs. euchromatin regions: light-stimulated production of oxidatively generated DNA lesions was obtained with Killer Red protein fused to transcription repressor, or activator cassettes integrated into distinct genomic loci [87]. Lastly, the chromatin unfolding effect 
induced by PARP-1 on the accessibility of DNA-binding vs. histone binding domains to DNA damage sites has been investigated by live-cell imaging and fluorescence lifetime measurements [88].

Using live-cell imaging techniques, software (e.g., ImageJ) for data processing play a fundamental role in imaging acquisition and analysis. In fact, they are helpful in compensating for common experimental issues, such as cell movement, which, especially during long time-lapse, may affect the accuracy of the analysis. This would bring about the inaccurate estimation of fluorescence intensity variations over time, which is at the basis of every kinetic parameter calculation. In particular, this experimental issue would affect the analysis because of the progressive misalignment along the frame sequence between the irradiated spot within the cell and the ROI selected for quantitative fluorescence analysis. However, cell movement during time-lapse experiments can often be corrected by using appropriate plugins (e.g., TurboReg, StackReg), which can align or match images taking advantage of landmarks manually or automatically selected on the image used as a template.

Recent studies have demonstrated that continuous wave $(\mathrm{CW})$ diode lasers, commonly used in confocal microscopy (emitting at 405, 488, or $561 \mathrm{~nm}$ ), can induce different types of DNA damage (e.g., CPD, SSB, DSB) according to the laser wavelength and to the amount of energy locally deposited, even in the absence of a pre-treatment with thymidine analogs $[63,89,90]$. In addition, exposure to high-intensity UV laser $(266 \mathrm{~nm})$ may induce base ionization and formation of oxidized bases [91]. Thus, a major caveat when using laser micro-beams is that it is not always possible to activate a specific DNA repair process exclusively, and careful evaluation of experimental conditions is to be taken into account. However, the induction of highly-localized DSBs with heavy ions overcomes this limitation, allowing high-resolution fluorescence imaging in living cells [92].

An important common issue occurring in live-cell imaging is photobleaching, a well-known phenomenon in fluorescence microscopy consisting of the gradual reduction of overall fluorescence intensity within the cell. It occurs because of fluorophore exposure to photon-induced chemical damage produced by light that finally leads to a reduction in the resolving power of the fluorescence microscope [93-95]. Another important light-induced effect that should be taken into account is phototoxicity arising from photophysical and photochemical processes leading to cellular damage $[96,97]$. In fact, the local formation of reactive oxygen species (ROS) can damage or destabilize biomolecules other than DNA. In addition, thermal effects due to local energy deposition can lead to protein denaturation [98]. Given that, live-cell imaging techniques should be accompanied by phototoxicity assessment to estimate the light-induced cellular damage, which may affect data reliability and reproducibility. Several biological criteria and physical parameters for phototoxicity evaluation have been identified, as discussed in detail in [99]. Nowadays, different solutions are available to reduce photobleaching and phototoxicity detrimental effects, such as the removal of vitamins riboflavin and pyridoxal from imaging medium [100,101], or the use of antioxidants to increase the chromophore photostability [102]. However, the most promising results have been obtained by optimizing the microscope illumination system to reach the best compromise between the amount of energy released and the fluorescence signal quality [103-105].

\section{Conclusions}

Investigations into radiation-induced DNA damage have led to the development and exploitation of several methods to detect DNA-protein interaction in situ. These studies have been fundamental for the understanding of several aspects of DDR, particularly for unraveling complex networks of protein binding to DNA for damage signaling and repair [8-12].

The different approaches in fixed vs. living cells must take into account that in the former, information obtained is more often only qualitative, providing localization, and at most temporal description, of the association of a given protein to DNA (e.g., at damaged sites). However, the use of the micropore filter irradiation technique is simple and does not require expensive instrumentation. Similarly, PLA and SIRF techniques have gained success thanks to the resolution provided, and for the relatively simple methodology. In contrast, the approach on living cells, such as fluorescence live-cell 
imaging, is undoubtedly a cutting-edge method providing high spatiotemporal resolution and is an essential tool for in situ kinetic studies. The possibility of measuring the fluorescence signal permits the quantification of the process in real-time, thereby allowing the estimation of important kinetic parameters of the reaction underlying the formation of the DNA-protein complex. In the face of these features, live-cell imaging requires more complex and expensive instrumentation.

In conclusion, the possibility to rely on different techniques, ranging from simple to more sophisticated ones, allows researchers to tackle biological problems from different points of view, to gain more insights into the study of radiation-induced DNA-protein interactions.

Author Contributions: Writing—original draft preparation, G.T.; writing—review and editing, E.P.

Funding: The research in the E.P. lab was funded by Associazione Italiana per la Ricerca sul Cancro (AIRC), grant number IG17041, and in part by the CNR Flagship Project "InterOmics".

Conflicts of Interest: The authors declare no conflict of interest. The funders had no role in the design of the study; in the collection, analyses, or interpretation of data; in the writing of the manuscript, or in the decision to publish the results.

\section{Abbreviations}

$\begin{array}{ll}\text { BER } & \text { Base Excision Repair } \\ \text { CPD } & \text { Cyclobutane Pyrimidine Dimer } \\ \text { DDR } & \text { DNA Damage Response } \\ \text { DSB } & \text { Double Strand Break } \\ \text { GFP } & \text { Green Fluorescent Protein } \\ \text { IR } & \text { Ionizing Radiation } \\ \text { NER } & \text { Nucleotide Excision Repair } \\ \text { NHEJ } & \text { Non Homologous End Joining } \\ \text { PCNA } & \text { Proliferating Cell Nuclear Antigen } \\ \text { PLA } & \text { Proximity Ligation Assay } \\ \text { iPOND } & \text { Isolation of Protein on Nascent DNA } \\ \text { SLA } & \text { Subcellular Localization Assay } \\ \text { SIRF } & \text { In Situ Protein Interactions at Nascent and Stalled } \\ & \text { Replication Forks } \\ \text { SSB } & \text { Single Strand Break }\end{array}$

\section{References}

1. Agarwal, S.; Tafel, A.A.; Kanaar, R. DNA double-strand breaks repair and chromosome translocation. DNA Repair 2006, 5, 1075-1081. [CrossRef] [PubMed]

2. Hoeijmakers, J.H.J. DNA damage, aging, and cancer. N. Engl. J. Med. 2009, 361, 1475-1485. [CrossRef] [PubMed]

3. Hanahan, D.; Weinberg, R. Hallmarks of cancer: The next generation. Cell 2011, 144, 646-674. [CrossRef] [PubMed]

4. Cadet, J.; Douki, T. Formation of UV-induced DNA damage contributing to skin cancer development. Photochem. Photobiol. Sci. 2018, 17, 1816-1841. [CrossRef]

5. Goodhead, D.T. Initial events in the cellular effects of ionizing radiations: Clustered damage in DNA. Int. J. Rad. Biol. 1994, 65, 7-17. [CrossRef]

6. Cadet, J.; Davies, K.J.A.; Medeiros, M.H.G.; Di Mascio, P.; Wagner, J.R. Formation and repair of oxidatively generated damage in cellular DNA. Free Radic. Biol. Med. 2017, 107, 13-34. [CrossRef]

7. Toulany, M. Targeting DNA double-strand breaks repair pathways to improve radiotherapy. Genes 2019, 10, 25. [CrossRef]

8. Ciccia, A.; Elledge, S.J. The DNA damage response: Making safe to play with knives. Mol. Cell 2010, 22, 179-204. [CrossRef]

9. Harper, J.W.; Elledge, S.J. The DNA damage response: Ten years after. Mol. Cell 2007, 28, 739-745. [CrossRef] 
10. Branzei, D.; Foiani, M. Regulation of DNA repair throughout the cell cycle. Nat. Rev. Mol. Cell Biol. 2008, 9 , 297-308. [CrossRef]

11. Polo, S.E.; Jackson, S.P. Dynamics of DNA damage response proteins at DNA breaks: A focus on protein modifications. Genes Dev. 2011, 25, 409-433. [CrossRef] [PubMed]

12. Kochan, J.A.; Desclos, E.C.B.; Bosch, R.; Meister, L.; Vriend, L.E.M.; van Attikum, H.; Krawczyk, P.M. Meta-analysis of DNA double-strand break response kinetics. Nucleic Acids Res. 2017, 45, 12625-12637. [CrossRef] [PubMed]

13. Misteli, T. Protein dynamics: Implications for nuclear architecture and gene expression. Science 2001, 291, 843-847. [CrossRef] [PubMed]

14. Toschi, L. Changes in cyclin/proliferating cell nuclear antigen distribution during DNA repair synthesis. J. Cell Biol. 1988, 107, 1623-1628. [CrossRef]

15. Prosperi, E.; Stivala, L.A.; Sala, E.; Scovassi, A.I.; Bianchi, L. Proliferating Cell Nuclear Antigen Complex Formation Induced by ultraviolet irradiation in human quiescent fibroblasts as detected by immunostaining and flow cytometry. Exp. Cell Res. 1993, 205, 320-325. [CrossRef]

16. Mirzoeva, O.K.; Petrini, J.H.J. DNA damage-dependent nuclear dynamics of the Mre11 complex. Mol. Cell. Biol. 2001, 21, 281-288. [CrossRef]

17. Tsien, R.Y. The green fluorescent protein. Ann. Rev. Biochem. 1998, 67, 509-544. [CrossRef]

18. Essers, J.; Houtsmuller, A.B.; van Veelen, L.; Paulusma, C.; Nigg, A.L.; Pastink, A.; Vermeulen, W.; Hoeijmakers, J.H.; Kanaar, R. Nuclear dynamics of RAD52 group homologous recombination proteins in response to DNA damage. EMBO J. 2002, 21, 2030-2037. [CrossRef]

19. Lukas, C.; Falck, J.; Bartkova, J.; Bartek, J.; Lukas, J. Distinct spatiotemporal dynamics of mammalian checkpoint regulators induced by DNA damage. Nat. Cell Biol. 2003, 5, 255-260. [CrossRef]

20. Moné, M.J.; Bernas, T.; Dinant, C.; Goedvree, F.A.; Manders, E.M.M.; Volker, M.; Houtsmuller, A.B.; Hoeijmakers, J.H.J.; Vermeulen, W.; Van Driel, R. In vivo dynamics of chromatin-associated complex formation in mammalian nucleotide excision repair. Proc. Natl. Acad. Sci. USA 2004, 101, 15933-15937. [CrossRef]

21. Tobias, F.; Löb, D.; Lengert, N.; Durante, M.; Drossel, B.; Taucher-Scholz, G.; Jakob, B. Spatiotemporal dynamics of early DNA damage response proteins on complex DNA lesions. PLoS ONE 2013, 8, e57953. [CrossRef]

22. Karanam, K.; Loewer, A.; Lahav, G. Dynamics of the DNA damage response: Insights from live-cell imaging. Brief. Funct. Genomics 2013, 12, 109-117. [CrossRef]

23. Prosperi, E. The fellowship of the rings: Distinct pools of proliferating cell nuclear antigen trimer at work. FASEB J. 2006, 20, 833-837. [CrossRef] [PubMed]

24. Moldovan, G.-L.; Pfander, B.; Jentsch, S. PCNA, the maestro of the replication fork. Cell 2007, 129, 665-679. [CrossRef] [PubMed]

25. Miura, M. Detection of Chromatin-bound PCNA in mammalian cells and its use to study DNA excision repair. J. Radiat. Res. 1999, 40,1-12. [CrossRef] [PubMed]

26. Scovassi, A.I.; Prosperi, E. Analysis of proliferating cell nuclear antigen (PCNA) associated with DNA excision repair sites in mammalian cells. Methods Mol. Biol. 2006, 314, 457-475. [CrossRef]

27. Katsumi, S.; Kobayashi, N.; Imoto, K.; Nakagawa, A.; Yamashina, Y.; Muramatsu, T.; Shirai, T.; Miyagawa, S.; Sugiura, S.; Hanaoka, F.; et al. In situ visualization of ultraviolet-light-induced DNA damage repair in locally irradiated human fibroblasts. J. Invest. Dermatol. 2001, 117, 1156-1161. [CrossRef]

28. Moné, M.J.; Volker, M.; Nikaido, O.; Mullenders, L.H.F.; van Zeeland, A.A.; Verschure, P.J.; Manders, E.M.M.; van Driel, R. Local UV-induced DNA damage in cell nuclei results in local transcription inhibition. EMBO Rep. 2001, 2, 1013-1017. [CrossRef]

29. Volker, M.; Moné, M.J.; Karmakar, P.; van Hoffen, A.; Schul, W.; Vermeulen, W.; Hoeijmakers, J.H.J.; Van Driel, R.; Van Zeeland, A.A.; Mullenders, L.H.F. Sequential assembly of the nucleotide excision repair factors in vivo. Mol. Cell 2001, 8, 213-224. [CrossRef]

30. Wakasugi, M.; Kawashima, A.; Morioka, H.; Linn, S.; Sancar, A.; Mori, T.; Nikaido, O.; Matsunaga, T. DDB accumulates at DNA damage sites immediately after UV irradiation and directly stimulates nucleotide excision repair. J. Biol. Chem. 2002, 277, 1637-1640. [CrossRef] 
31. Oh, K.-S.; Imoto, K.; Boyle, J.; Khan, S.G.; Kraemer, K.H. Influence of XPB helicase on recruitment and redistribution of nucleotide excision repair proteins at sites of UV-induced DNA damage. DNA Repair 2007, 6, 1359-1370. [CrossRef] [PubMed]

32. Thorel, F.; Constantinou, A.; Dunand-Sauthier, I.; Nouspikel, T.; Lalle, P.; Raams, A.; Jaspers, N.G.J.; Vermeulen, W.; Shivji, M.K.K.; Wood, R.D.; et al. Definition of a short region of XPG necessary for TFIIH interaction and stable recruitment to sites of UV damage. Mol. Cell. Biol. 2004, 24, 10670-10680. [CrossRef] [PubMed]

33. Mocquet, V.; Lainé, J.P.; Riedl, T.; Yajin, Z.; Lee, M.Y.; Egly, J.M. Sequential recruitment of the repair factors during NER: The role of XPG in initiating the resynthesis step. EMBO J. 2008, 27, 155-167. [CrossRef] [PubMed]

34. Chea, J.; Zhang, S.; Zhao, H.; Zhang, Z.; Lee, E.Y.C.; Darzynkiewicz, Z.; Lee, M.Y.W.T. Spatiotemporal recruitment of human DNA polymerase delta to sites of UV damage. Cell Cycle 2012, 11, 2885-2895. [CrossRef]

35. Ogi, T.; Limsirichaikul, S.; Overmeer, R.M.; Volker, M.; Takenaka, K.; Cloney, R.; Nakazawa, Y.; Niimi, A.; Miki, Y.; Jaspers, N.G.; et al. Three DNA polymerases, recruited by different mechanisms, carry out NER repair synthesis in human cells. Mol. Cell 2010, 37, 714-727. [CrossRef]

36. Green, C.M.; Almouzni, G. Local action of the chromatin assembly factor CAF-1 at sites of nucleotide excision repair in vivo. EMBO J. 2003, 22, 5163-5174. [CrossRef]

37. Al Rashid, S.T.; Dellaire, G.; Cuddihy, A.; Jalali, F.; Vaid, M.; Coackley, C.; Folkard, M.; Xu, Y.; Chen, B.P.C.; Chen, D.J.; et al. Evidence for the direct binding of phosphorylated p53 to sites of DNA breaks in vivo. Cancer Res. 2005, 65, 10810-10821. [CrossRef]

38. Fitch, M.E.; Cross, I.V.; Ford, J.M. p53 responsive nucleotide excision repair gene products p48 and XPC, but not p53, localize to sites of UV-irradiation-induced DNA damage, in vivo. Carcinogenesis 2003, 24, 843-850. [CrossRef]

39. Rubbi, C.P.; Milner, J. p53 is a chromatin accessibility factor for nucleotide excision repair of DNA damage. EMBO J. 2003, 22, 975-986. [CrossRef]

40. Polo, S.E.; Roche, D.; Almouzni, G. New histone incorporation marks sites of UV repair in human cells. Cell 2006, 127, 481-493. [CrossRef]

41. Zhu, Q.; Wei, S.; Sharma, N.; Wani, G.; He, J.; Wani, A.A. Human CRL4 ${ }^{\text {DDB2 }}$ ubiquitin ligase preferentially regulates post-repair chromatin restoration of H3K56Ac through recruitment of histone chaperon CAF-1. Oncotarget 2017, 8, 104525-104542. [CrossRef] [PubMed]

42. Wang, Q.-E.; Zhu, Q.; Wani, G.; Chen, J.; Wani, A.A. UV radiation-induced XPC translocation within chromatin is mediated by damaged-DNA binding protein, DDB2. Carcinogenesis 2004, 25, 1033-1043. [CrossRef] [PubMed]

43. Dutto, I.; Cazzalini, O.; Stivala, L.A.; Prosperi, E. An improved method for the detection of nucleotide excision repair factors at local UV DNA damage sites. DNA Repair 2017, 51, 79-84. [CrossRef] [PubMed]

44. Michaelsen, K.; Krishnaswamy, V.; Pogue, B.W.; Brooks, K.; Defreitas, K.; Shaw, I.; Poplack, S.P.; Paulsen, K.D. Characterization of materials for optimal near-infrared and $\mathrm{x}$-ray imaging of the breast. Biomed. Opt. Express 2012, 3, 2078. [CrossRef] [PubMed]

45. Fredriksson, S.; Gullberg, M.; Jarvius, J.; Olsson, C.; Pietras, K.; Gústafsdóttir, S.M.; Östman, A.; Landegren, U. Protein detection using proximity-dependent DNA ligation assays. Nat. Biotechnol. 2002, 20, 473-477. [CrossRef]

46. Pan, Y.; Sackmann, E.K.; Wypisniak, K.; Hornsby, M.; Datwani, S.S.; Herr, A.E. Determination of equilibrium dissociation constants for recombinant antibodies by high-throughput affinity electrophoresis. Sci. Rep. 2016, 6, 39774. [CrossRef]

47. Klaesson, A.; Grannas, K.; Ebai, T.; Heldin, J.; Koos, B.; Leino, M.; Raykova, D.; Oelrich, J.; Arngården, L.; Söderberg, O.; et al. Improved efficiency of in situ protein analysis by proximity ligation using UnFold probes. Sci. Rep. 2018, 8, 5400. [CrossRef]

48. Burns, T.J.; Frei, A.P.; Gherardini, P.F.; Bava, F.A.; Batchelder, J.E.; Yoshiyasu, Y.; Yu, J.M.; Groziak, A.R.; Kimmey, S.C.; Gonzalez, V.D.; et al. High-throughput precision measurement of subcellular localization in single cells: High-throughput precision measurement of SLA. Cytometry 2017, 91, 180-189. [CrossRef]

49. Serebryannyy, L.A.; Misteli, T. HiPLA: High-throughput imaging proximity ligation assay. Methods 2019, 157, 80-87. [CrossRef] 
50. Debaize, L.; Jakobczyk, H.; Rio, A.-G.; Gandemer, V.; Troadec, M.-B. Optimization of proximity ligation assay (PLA) for detection of protein interactions and fusion proteins in non-adherent cells: Application to pre-B lymphocytes. Mol. Cytogenet. 2017, 10, 27. [CrossRef]

51. Bahjat, M.; Bloedjes, T.A.; van der Veen, A.; de Wilde, G.; Maas, C.; Guikema, J.E.J. Detection and visualization of DNA Damage-induced protein complexes in suspension cell cultures using the proximity ligation assay. JoVE 2017, 124, e55703. [CrossRef]

52. Rassoolzadeh, H.; Coucoravas, C.; Farnebo, M. The proximity ligation assay reveals that at DNA double-strand breaks WRAP53 $\beta$ associates with $\gamma \mathrm{H} 2 \mathrm{AX}$ and controls interactions between RNF8 and MDC1. Nucleus 2015, 6, 417-424. [CrossRef] [PubMed]

53. Marin-Vicente, C.; Domingo-Prim, J.; Eberle, A.B.; Visa, N. RRP6/EXOSC10 is required for the repair of DNA double-strand breaks by homologous recombination. J. Cell Sci. 2015, 128, 1097-1107. [CrossRef] [PubMed]

54. Yin, Y.; Li, R.; Xu, K.; Ding, S.; Li, J.; Baek, G.; Ramanand, S.G.; Ding, S.; Liu, Z.; Gao, Y.; et al. Androgen receptor variants mediate DNA repair after prostate cancer irradiation. Cancer Res. 2017, 77, 4745-4754. [CrossRef]

55. Song, K.-H.; Jung, S.-Y.; Park, J.-I.; Ahn, J.; Park, J.K.; Um, H.-D.; Park, I.-C.; Hwang, S.-G.; Ha, H.; Song, J.-Y. Inhibition of karyopherin- $\alpha 2$ augments radiation-induced cell death by perturbing BRCA1-mediated DNA repair. Int. J. Mol. Sci. 2019, 20, 2843. [CrossRef]

56. Galbiati, A.; Beauséjour, C.; d'Adda di Fagagna, F. A novel single-cell method provides direct evidence of persistent DNA damage in senescent cells and aged mammalian tissues. Aging Cell 2017, 16, 422-427. [CrossRef]

57. Roy, S.; Luzwick, J.W.; Schlacher, K. SIRF: Quantitative in situ analysis of protein interactions at DNA replication forks. J. Cell Biol. 2018, 217, 1521-1536. [CrossRef]

58. Crosetto, N.; Mitra, A.; Silva, M.J.; Bienko, M.; Dojer, N.; Wang, Q.; Karaca, E.; Chiarle, R.; Skrzypczak, M.; Ginalski, K.; et al. Nucleotide-resolution DNA double-strand break mapping by next-generation sequencing. Nat. Methods 2013, 10, 361-365. [CrossRef]

59. Weibrecht, I.; Gavrilovic, M.; Lindbom, L.; Landegren, U.; Wählby, C.; Söderberg, O. Visualising individual sequence-specific protein-DNA interactions in situ. New Biotechnol. 2012, 29, 589-598. [CrossRef]

60. Sirbu, B.M.; Couch, F.B.; Feigerle, J.T.; Bhaskara, S.; Hiebert, S.W.; Cortez, D. Analysis of protein dynamics at active, stalled, and collapsed replication forks. Genes Dev. 2011, 25, 1320-1327. [CrossRef]

61. Cremer, C.; Cremer, T.; Fukuda, M.; Nakanishi, K. Detection of laser-UV microirradiation-induced DNA photolesions by immunofluorescent staining. Hum. Genet. 1980, 54, 107-110. [CrossRef] [PubMed]

62. Tashiro, S.; Walter, J.; Shinohara, A.; Kamada, N.; Cremer, T. Rad51 Accumulation at sites of DNA damage and in postreplicative chromatin. J. Cell Biol. 2000, 150, 283-292. [CrossRef] [PubMed]

63. Dinant, C.; de Jager, M.; Essers, J.; van Cappellen, W.A.; Kanaar, R.; Houtsmuller, A.B.; Vermeulen, W. Activation of multiple DNA repair pathways by sub-nuclear damage induction methods. J. Cell Sci. 2007, 120, 2731-2740. [CrossRef] [PubMed]

64. Houtsmuller, A.B.; Vermeulen, W. Macromolecular dynamics in living cell nuclei revealed by fluorescence redistribution after photobleaching. Histochem. Cell Biol. 2001, 115, 13-21. [CrossRef]

65. Vermeulen, W. Dynamics of mammalian NER proteins. DNA Repair 2011, 10, 760-771. [CrossRef]

66. Lan, L.; Nakajima, S.; Oohata, Y.; Takao, M.; Okano, S.; Masutani, M.; Wilson, S.H.; Yasui, A. In situ analysis of repair processes for oxidative DNA damage in mammalian cells. Proc. Natl. Acad. Sci. USA 2004, 101, 13738-13743. [CrossRef]

67. Luijsterburg, M.S.; von Bornstaedt, G.; Gourdin, A.M.; Politi, A.Z.; Moné, M.J.; Warmerdam, D.O.; Goedhart, J.; Vermeulen, W.; van Driel, R.; Höfer, T. Stochastic and reversible assembly of a multiprotein DNA repair complex ensures accurate target site recognition and efficient repair. J. Cell Biol. 2010, 189, 445-463. [CrossRef]

68. Cazzalini, O.; Sommatis, S.; Tillhon, M.; Dutto, I.; Bachi, A.; Rapp, A.; Nardo, T.; Scovassi, A.I.; Necchi, D.; Cardoso, M.C.; et al. CBP and p300 acetylate PCNA to link its degradation with nucleotide excision repair synthesis. Nucleic Acids Res. 2014, 42, 8433-8448. [CrossRef]

69. Lengert, L.; Lengert, N.; Drossel, B.; Cardoso, M.C.; Muster, B.; Nowak, D.; Rapp, A. Discrimination of kinetic models by a combination of microirradiation and fluorescence photobleaching. Biophys. J. 2015, 109, 1551-1564. [CrossRef] 
70. Perucca, P.; Cazzalini, O.; Mortusewicz, O.; Necchi, D.; Savio, M.; Nardo, T.; Stivala, L.A.; Leonhardt, H.; Cardoso, M.C.; Prosperi, E. Spatiotemporal dynamics of p21 CDKN1A protein recruitment to DNA-damage sites and interaction with proliferating cell nuclear antigen. J. Cell Sci. 2006, 119, 1517-1527. [CrossRef]

71. Mortusewicz, O.; Leonhardt, H. XRCC1 and PCNA are loading platforms with distinct kinetic properties and different capacities to respond to multiple DNA lesions. BMC Mol. Biol. 2007, 8, 81. [CrossRef] [PubMed]

72. Mortusewicz, O.; Leonhardt, H.; Cardoso, M.C. Spatiotemporal dynamics of regulatory protein recruitment at DNA damage sites. J. Cell. Biochem. 2008, 104, 1562-1569. [CrossRef] [PubMed]

73. Campalans, A.; Kortulewski, T.; Amouroux, R.; Menoni, H.; Vermeulen, W.; Radicella, J.P. Distinct spatiotemporal patterns and PARP dependence of XRCC1 recruitment to single-strand break and base excision repair. Nucleic Acids Res. 2013, 41, 3115-3129. [CrossRef]

74. Mortusewicz, O.; Amé, J.-C.; Schreiber, V.; Leonhardt, H. Feedback-regulated poly(ADP-ribosyl)ation by PARP-1 is required for rapid response to DNA damage in living cells. Nucleic Acids Res. 2007, 35, 7665-7675. [CrossRef]

75. Strickfaden, H.; McDonald, D.; Kruhlak, M.J.; Haince, J.-F.; Th'ng, J.P.H.; Rouleau, M.; Ishibashi, T.; Corry, G.N.; Ausio, J.; Underhill, D.A.; et al. Poly(ADP-ribosyl)ation-dependent transient chromatin decondensation and histone displacement following laser microirradiation. J. Biol. Chem. 2016, 291, 1789-1802. [CrossRef]

76. Garbrecht, J.; Hornegger, H.; Herbert, S.; Kaufmann, T.; Gotzmann, J.; Elsayad, K.; Slade, D. Simultaneous dual-channel imaging to quantify interdependent protein recruitment to laser-induced DNA damage sites. Nucleus 2018, 9, 474-491. [CrossRef]

77. Haince, J.-F.; McDonald, D.; Rodrigue, A.; Déry, U.; Masson, J.-Y.; Hendzel, M.J.; Poirier, G.G. PARP1-dependent kinetics of recruitment of MRE11 and NBS1 proteins to multiple DNA damage sites. J. Biol. Chem. 2008, 283, 1197-1208. [CrossRef]

78. Weterings, E.; Verkaik, N.S.; Keijzers, G.; Florea, B.I.; Wang, S.-Y.; Ortega, L.G.; Uematsu, N.; Chen, D.J.; van Gent, D.C. The Ku80 carboxy terminus stimulates joining and artemis-mediated processing of DNA ends. Mol. Cell. Biol. 2009, 29, 1134-1142. [CrossRef]

79. Reynolds, P.; Anderson, J.A.; Harper, J.V.; Hill, M.A.; Botchway, S.W.; Parker, A.W.; O’Neill, P. The dynamics of Ku70/80 and DNA-PKcs at DSBs induced by ionizing radiation is dependent on the complexity of damage. Nucleic Acids Res. 2012, 40, 10821-10831. [CrossRef]

80. Mortusewicz, O.; Rothbauer, U.; Cardoso, M.C.; Leonhardt, H. Differential recruitment of DNA Ligase I and III to DNA repair sites. Nucleic Acids Res. 2006, 34, 3523-3532. [CrossRef]

81. Gassman, N.R.; Holton, N.W. Targets for repair: Detecting and quantifying DNA damage with fluorescence-based methodologies. Curr. Opin. Biotech. 2019, 55, 30-35. [CrossRef] [PubMed]

82. Pedersen, R.S.; Karemore, G.; Gudjonsson, T.; Rask, M.-B.; Neumann, B.; Hériché, J.-K.; Pepperkok, R.; Ellenberg, J.; Gerlich, D.W.; Lukas, J.; et al. Profiling DNA damage response following mitotic perturbations. Nat. Commun. 2016, 7, 13887. [CrossRef] [PubMed]

83. Yang, K.S.; Kohler, R.H.; Landon, M.; Giedt, R.; Weissleder, R. Single cell resolution in vivo imaging of DNA damage following PARP inhibition. Sci. Rep. 2015, 5, 10129. [CrossRef] [PubMed]

84. Steurer, B.; Turkyilmaz, Y.; Van Toorn, M.; Van Leeuwen, W.; Escudero-Ferruz, P.; Marteijn, J.A. Fluorescently-labelled CPD and 6-4PP photolyases: New tools for live-cell DNA damage quantification and laser-assisted repair. Nucleic Acids Res. 2019, 47, 3536-3549. [CrossRef]

85. Woodrick, J.; Gupta, S.; Khatkar, P.; Dave, K.; Levashova, D.; Choudhury, S.; Elias, H.; Saha, T.; Mueller, S.; Roy, R. A novel method for monitoring functional lesion-specific recruitment of repair proteins in live cells. Mutat. Res. 2015, 775, 48-58. [CrossRef]

86. Herce, H.D.; Deng, W.; Helma, J.; Leonhardt, H.; Cardoso, M.C. Visualization and targeted disruption of protein interactions in living cells. Nat. Commun. 2013, 4, 2660. [CrossRef]

87. Lan, L.; Nakajima, S.; Wei, L.; Sun, L.; Hsieh, C.-L.; Sobol, R.W.; Bruchez, M.; Van Houten, B.; Yasui, A.; Levine, A.S. Novel method for site-specific induction of oxidative DNA damage reveals differences in recruitment of repair proteins to heterochromatin and euchromatin. Nucleic Acids Res. 2014, 42, 2330-2345. [CrossRef]

88. Smith, R.; Lebeaupin, T.; Juhász, S.; Chapuis, C.; D’Augustin, O.; Dutertre, S.; Burkovics, P.; Biertümpfel, C.; Timinszky, G.; Huet, S. Poly(ADP-ribose)-dependent chromatin unfolding facilitates the association of DNA-binding proteins with DNA at sites of damage. Nucleic Acids Res. 2019, in press. [CrossRef] 
89. Reynolds, P.; Botchway, S.W.; Parker, A.W.; O'Neill, P. Spatiotemporal dynamics of DNA repair proteins following laser microbeam induced DNA damage - When is a DSB not a DSB? Mutat. Res. 2013, 756, 14-20. [CrossRef]

90. Muster, B.; Rapp, A.; Cardoso, M.C. Systematic analysis of DNA damage induction and DNA repair pathway activation by continuous wave visible light laser micro-irradiation. AIMS Genetics 2017, 4, 47-68. [CrossRef]

91. Cadet, J.; Wagner, J.R.; Angelov, D. Biphotonic ionization of DNA: From model studies to cell. Photochem. Photobiol. 2019, 95, 59-72. [CrossRef]

92. Jakob, B.; Rudolph, J.H.; Gueven, N.; Lavin, M.F.; Taucher-Scholz, G. Live cell imaging of heavy-ion-induced radiation responses by beamline microscopy. Radiat. Res. 2005, 163, 681-690. [CrossRef]

93. Tsien, R.Y.; Ernst, L.; Waggoner, A. Fluorophores for confocal microscopy: Photophysics and photochemistry. In Handbook of Biological Confocal Microscopy; Pawley, J.B., Ed.; Springer: Boston, MA, USA, 2006; pp. 338-352. ISBN 978-0-387-25921-5. [CrossRef]

94. Bernas, T.; Zarebski, M.; Cook, R.R.; Dobrucki, J.W. Minimizing photobleaching during confocal microscopy of fluorescent probes bound to chromatin: Role of anoxia and photon flux. J. Microsc. 2004, 215, 281-296. [CrossRef]

95. Bernas, T.; Robinson, J.P.; Asem, E.K.; Rajwa, B. Loss of image quality in photobleaching during microscopic imaging of fluorescent probes bound to chromatin. J. Biomed. Opt. 2005, 10, 064015. [CrossRef]

96. Anonymous. Artifacts of light. Nat. Methods 2013, 10, 1135. [CrossRef]

97. Daddysman, M.K.; Tycon, M.A.; Fecko, C.J. Photoinduced damage resulting from fluorescence imaging of live cells. In Photoswitching Proteins; Cambridge, S., Ed.; Springer: New York, NY, USA, 2014; Volume 1148, pp. 1-17. ISBN 978-1-4939-0469-3. [CrossRef]

98. Vogel, A.; Noack, J.; Hüttman, G.; Paltauf, G. Mechanisms of femtosecond laser nanosurgery of cells and tissues. Appl. Phys. B 2005, 81, 1015-1047. [CrossRef]

99. Laissue, P.P.; Alghamdi, R.A.; Tomancak, P.; Reynaud, E.G.; Shroff, H. Assessing phototoxicity in live fluorescence imaging. Nat. Methods 2017, 14, 657-661. [CrossRef]

100. Bogdanov, A.M.; Bogdanova, E.A.; Chudakov, D.M.; Gorodnicheva, T.V.; Lukyanov, S.; Lukyanov, K.A. Cell culture medium affects GFP photostability: A solution. Nat. Methods 2009, 6, 859-860. [CrossRef]

101. Stockley, J.H.; Evans, K.; Matthey, M.; Volbracht, K.; Agathou, S.; Mukanowa, J.; Burrone, J.; Káradóttir, R.T. Surpassing light-induced cell damage in vitro with novel cell culture media. Sci. Rep. 2017, 7, 849. [CrossRef]

102. Bogdanov, A.M.; Kudryavtseva, E.I.; Lukyanov, K.A. Anti-fading media for live cell GFP imaging. PLoS ONE 2012, 7, e53004. [CrossRef]

103. Magidson, V.; Khodjakov, A. Circumventing photodamage in live-cell microscopy. Methods Cell Biol. 2013, 114, 545-560. [CrossRef] [PubMed]

104. Boudreau, C.; Wee, T.-L.; Duh, Y.-R.; Couto, M.P.; Ardakani, K.H.; Brown, C.M. Excitation light dose engineering to reduce photo-bleaching and photo-toxicity. Sci. Rep. 2016, 6, 30892. [CrossRef] [PubMed]

105. Icha, J.; Weber, M.; Waters, J.C.; Norden, C. Phototoxicity in live fluorescence microscopy, and how to avoid it. BioEssays 2017, 39, 1700003. [CrossRef] [PubMed]

(C) 2019 by the authors. Licensee MDPI, Basel, Switzerland. This article is an open access article distributed under the terms and conditions of the Creative Commons Attribution (CC BY) license (http://creativecommons.org/licenses/by/4.0/). 